\title{
Article \\ A Highly Specific Holin-Mediated Mechanism Facilitates the Secretion of Lethal Toxin TcsL in Paeniclostridium sordellii
}

\author{
Callum J. Vidor ${ }^{1,2}$, Audrey Hamiot ${ }^{3,+}$, Jessica Wisniewski ${ }^{1}$, Rommel A. Mathias ${ }^{1,4}$, Bruno Dupuy ${ }^{3}$, \\ Milena Awad ${ }^{1, \ddagger}$ and Dena Lyras ${ }^{1, *, \ddagger}$
}

1 Infection and Immunity Program, Monash Biomedicine Discovery Institute and Department of Microbiology, Monash University, Clayton, VIC 3800, Australia; callum.vidor@monash.edu (C.J.V.); jess.wisniewski@monash.edu (J.W.); rommel.mathias@csl.com.au (R.A.M.); milena.awad@monash.edu (M.A.)

2 School of Biological Sciences, Monash University, Clayton, VIC 3800, Australia

3 Laboratoire Pathogenèse des Bactéries Anaérobies, UMR-CNRS 6047, Institut Pasteur, Université de Paris, F-75015 Paris, France; Audrey.Hamiot@inrae.fr (A.H.); bruno.dupuy@pasteur.fr (B.D.)

4 Infection and Immunity Program, Monash Biomedicine Discovery Institute and Department of Biochemistry and Molecular Biology, Monash University, Clayton, VIC 3800, Australia

* Correspondence: dena.lyras@monash.edu

† Current address: INRA, UMR UMET, F-59655 Villeneuve d'Ascq, France.

$\ddagger$ These authors contributed equally to this work.

check for updates

Citation: Vidor, C.J.; Hamiot, A.; Wisniewski, J.; Mathias, R.A.; Dupuy, B.; Awad, M.; Lyras, D. A Highly Specific Holin-Mediated Mechanism Facilitates the Secretion of Lethal Toxin TcsL in Paeniclostridium sordellii. Toxins 2022, 14, 124. https://doi.org/ $10.3390 /$ toxins 14020124

Received: 22 December 2021

Accepted: 4 February 2022

Published: 8 February 2022

Publisher's Note: MDPI stays neutral with regard to jurisdictional claims in published maps and institutional affiliations.

Copyright: (C) 2022 by the authors. Licensee MDPI, Basel, Switzerland. This article is an open access article distributed under the terms and conditions of the Creative Commons Attribution (CC BY) license (https:// creativecommons.org/licenses/by/ $4.0 /)$.

\begin{abstract}
Protein secretion is generally mediated by a series of distinct pathways in bacteria. Recently, evidence of a novel bacterial secretion pathway involving a bacteriophage-related protein has emerged. TcdE, a holin-like protein encoded by toxigenic isolates of Clostridioides difficile, mediates the release of the large clostridial glucosylating toxins (LCGTs), TcdA and TcdB, and TpeL from C. perfringens uses another holin-like protein, TpeE, for its secretion; however, it is not yet known if TcdE or TpeE secretion is specific to these proteins. It is also unknown if other members of the LCGT-producing clostridia, including Paeniclostridium sordellii (previously Clostridium sordellii), use a similar toxin-release mechanism. Here, we confirm that each of the LCGT-producing clostridia encode functional holin-like proteins in close proximity to the toxin genes. To characterise the respective roles of these holin-like proteins in the release of the LCGTs, P. sordellii and its lethal toxin, TcsL, were used as a model. Construction and analysis of mutants of the P. sordellii tcsE (holin-like) gene demonstrated that TcsE plays a significant role in TcsL release. Proteomic analysis of the secretome from the tcsE mutant confirmed that TcsE is required for efficient TcsL secretion. Unexpectedly, comparative sample analysis showed that TcsL was the only protein significantly altered in its release, suggesting that this holin-like protein has specifically evolved to function in the release of this important virulence factor. This specificity has, to our knowledge, not been previously shown and suggests that this protein may function as part of a specific mechanism for the release of all LCGTs.
\end{abstract}

Keywords: Paeniclostridium sordellii; Clostridioides difficile; large clostridial glucosylating toxins; toxin secretion; holins; protein secretion

Key Contribution: The findings presented here provide strong support for the involvement of a holin-like protein in the secretion of the toxin TcsL from the Large Clostridial Glucosylating Toxinproducing pathogen $P$. sordellii; and provide supportive evidence of the presence of holin-mediated secretion systems in bacteria.

\section{Introduction}

Protein secretion, defined as the transport of proteins from the cell cytoplasm to the extracellular milieu or into a target cell [1], is a critically important process in all bacteria. In pathogenic bacteria, the substrates of protein secretion systems are often virulence factors that induce host damage or cellular changes [2]. For diderm (Gram-negative) bacterial cells, 
the secretion process involves proteins crossing the cytoplasmic membrane $(\mathrm{CM})$, transferring through the periplasm, and then traversing the outer-membrane [1]. To achieve this complex process, diderm bacteria have developed a number of distinct secretion systems, with nine major types currently defined [3]. In monoderm (Gram-positive) bacterial cells, this process appears to be simpler since proteins must only cross a single cellular membrane to be secreted [1]. Once past the CM, secreted proteins often passively diffuse through the peptidoglycan layer [2]. Most proteins secreted by monoderms utilise two main pathways to cross the CM: the general secretion (Sec) or the twin arginine translocation (Tat) pathway [4]. Although there are features common to both pathways, the transport mechanism of each is different, with the Sec pathway transporting unfolded proteins, whereas the Tat pathway translocates folded proteins [2,4]. Transport by either system requires that the substrate protein contains a specific secretion signal recognition sequence, or signal peptide, at its N-terminus [2].

Many pathogenic bacteria utilise protein secretion mechanisms to release potent exotoxins that damage the host [2]. The clostridia, which are Gram-positive, strictly anaerobic, spore forming bacteria, are one such genus [5]. Some clostridial exotoxins appear to have signal peptides to facilitate their release from the cell [6-8]; however, others do not have any identifiable signal peptides, and the secretion process for these is not known [9-11]. Large clostridial glucosylating toxins (LCGTs) belong to the latter group. LCGTs are large (191-308 kDa) single-chain toxins [11,12] that function in mammalian target cells by glucosylating small GTPases, usually of the Rho or Ras family, leading to cytoskeletal rearrangement, cell rounding, and death [13]. LCGTs include TcdA and TcdB from Clostridioides difficile, TcsH (haemorrhagic toxin) and TcsL (lethal toxin) from Clostridium sordellii (renamed Paeniclostridium sordellii), TpeL from Clostridium perfringens, and Tcn $\alpha$ (alpha toxin) from Clostridium novyi [11,12]. The spectrum of diseases associated with these toxins is broad and depends on the site of infection and on differences in the specific cellular receptors and GTPase targets for each toxin $[13,14]$.

In C. difficile, the LCGTs are encoded at a defined chromosomal site called the Pathogenicity Locus (PaLoc) (Figure 1) [15]. As well as the genes $t c d A$ and $t c d B$, PaLoc encodes the accessory genes $t c d R, t c d C$ and $t c d E$ [15]. TcdR is an alternative sigma factor and a positive regulator of PaLoc genes [16,17], whereas TcdC appears to be an anti-sigma factor that negatively regulates toxin production [18,19], although this is contentious [20]. As for all LCGTs, TcdA and TcdB do not carry any recognisable signal peptides to indicate that they are secreted by one of the classical pathways. However, the holin-like protein TcdE seems to play a major role in their secretion [10], although a coexisting bacteriolytic mechanism also facilitates the release of the toxins in vitro, under certain growth conditions [21]. Furthermore, it has recently been shown that TpeE, a holin-like protein, is required for the secretion of the $C$. perfringens LCGT TpeL, which reinforces the role of a holin-dependent secretion system [22]. Holins are transmembrane proteins associated with the lytic lifecycle of bacteriophages. At the time of viral exit, holins will oligomerise in the $\mathrm{CM}$, forming a pore through which a peptidoglycan-degrading endolysin transits, thereby compromising the bacterial cell wall and resulting in cellular lysis and bacteriophage release [23]. Despite holins being associated with cell lysis mechanisms [23,24], the holin-mediated release of C. difficile LCGTs is non-lytic $[10,25]$. 


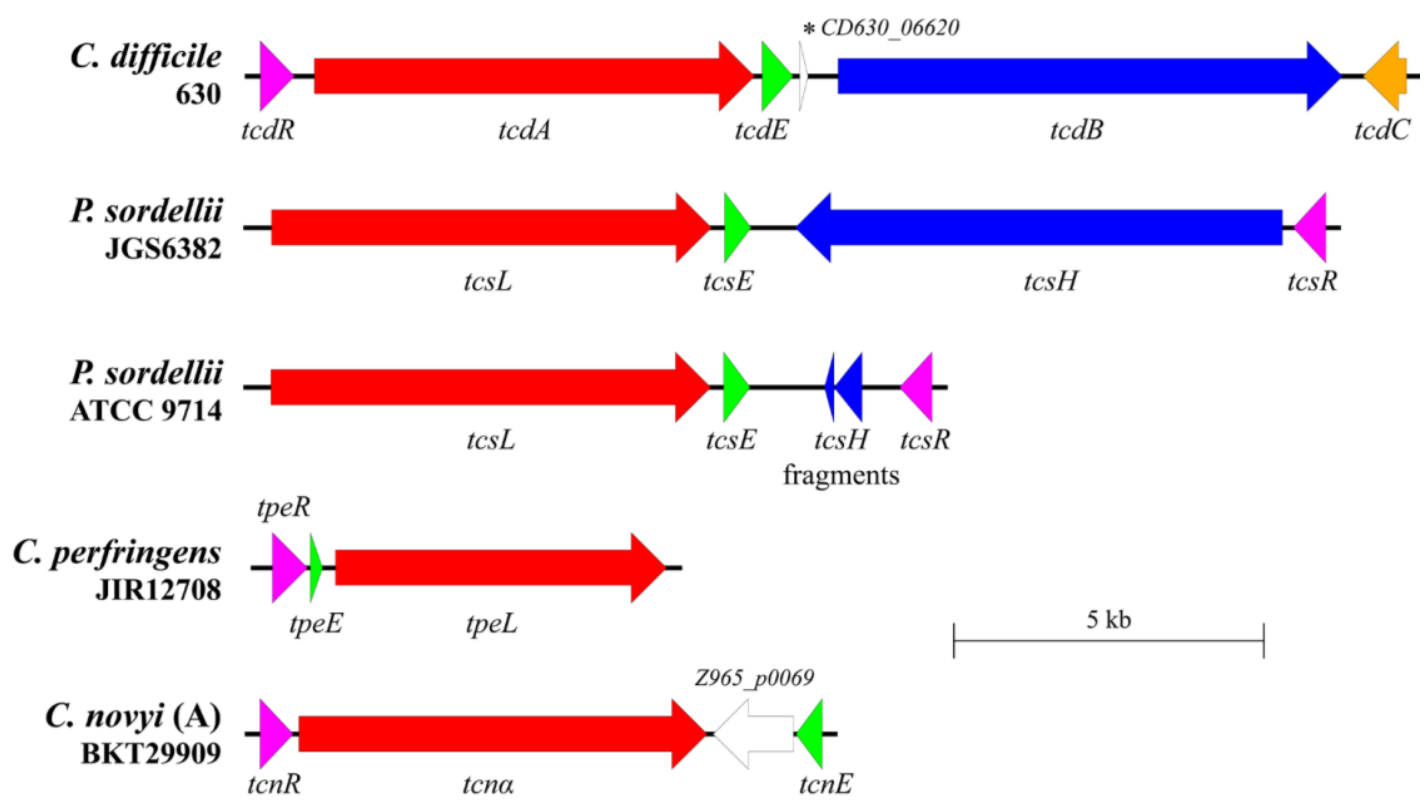

Figure 1. The PaLoc-like regions encoding clostridial LCGTs. Shown are the ORFs encoded within the PaLocs of $C$. difficile, P. sordellii, C. perfringens and C. novyi. Strain names are indicated under each species. Genes encoding orthologous products are indicated with the same colour: $t c d B$-like LCGT, red; $t c d A$-like LCGT, dark blue; alternative sigma factor/positive regulator, purple; transcriptional repressor, orange; holin-like protein, green; other ORFs, white. Produced using EasyFig [26].

More broadly, the role of holins in protein secretion is controversial [27]. Phageencoded holins have been implicated in the increased release of extracellular toxins, such as SheA and Stx1 in Escherichia coli $[28,29]$. Furthermore, bacterially encoded holin-like proteins have been shown to mediate chitinase release in Serratia marcescens [30]. One reason why holin-mediated systems may not be fully accepted as true bacterial secretion systems is that, with respect to phages, the roles of holins is to passively enable the transfer of folded endolysins into the periplasm [27], resulting in cellular lysis [23]. Neither of these processes are associated with specificity of protein release. Despite this, in the bacterialassociated holin-secretion mechanism, studies have observed the non-lytic nature and lack of cytoplasmic leakage [10,30], while the specificity of such a system has not yet been conclusively validated. This study aimed to extend investigation of the secretion mechanisms associated with the LCGTs encoded by a number of pathogenic clostridial species and their specificity using $P$. sordellii as a model organism. Here, we show that the P. sordellii LCGT TcsL requires a holin, TcsE, for efficient secretion, and that TcsL appears to be the only protein secreted by TcsE in P. sordellii, suggesting that the holin-mediated release for the clostridial LCGTs is highly specific.

\section{Results}

\subsection{Putative Holins Are Encoded within the PaLoc Regions of Pathogenic Clostridial Species}

All LCGT-encoding PaLoc regions of the pathogenic clostridia [15,22,31,32] encode homologues of TcdE and the alternative sigma factor TcdR (Figure 1). The C. novyi PaLoc also encodes homologues of $t c d E(t n c E)$ and $t c d R(t c n R)$, shown here by examining the closed phage genome from strain BKT29909 (Figure 1). These holin-like proteins vary between the clostridia, both in their predicted molecular weights and transmembrane domains (Figure 2). Furthermore, apart from TcdE and TcsE which appear related, there is limited protein identify among the clostridial holin proteins (Figure 2). However, the presence of holin-like proteins encoded by each of these clostridial PaLocs suggests that they may play a similar role to that of TcdE and therefore act to release their respective LCGTs. This suggestion is again supported by the recent finding that TpeE from C. perfringens controls the secretion of the LCGT TpeL, despite the obvious difference in structure and identify to 
the other clostridial holins (Figure 2) [22]. It has been noted that TpeE has more similarity to TatA-like holins, displaying $89 \%$ identify to the holin UviB from C. perfringens [22].

(a)

S105 ( $\lambda$ phage) $\operatorname{TcdE}(C$. dif.) TCsE (P. Sor.)

TpeE (C. per.)

TCnE (C. nov.)

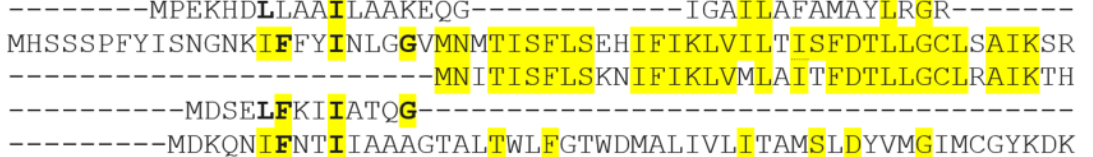

33

60

36

13

51

S105 ( $\lambda$ phage) -YNGGAFTKTVIDATMCAI IAWFIRDLLDF-------------A-----GLSSN TCdE ( $C$. dif.) KFNSSFGIDGGIRKVAM---IACIFFLSVVDILTKFNFLFMLPQDCINFLRLKHLGISEF

TCSE ( $P$. sor.) KFNSSFGINGGIRKIAM---IACIFFLSIVDMLTQFNFLFILPQEYINFFRFQHLGISEF

TpeE ( $C$. per. ) -

TCnE (C. nov.) NLSSSKGFRGLTKKFTI---LIILILAVCLDRLIGQGWV-----------------FRTI

S105 $\lambda$ phage

TcdE (C. dif.)

$\operatorname{TCSE}(P$. Sor.) FsM

TpeE (C. per.)

$\operatorname{TcnE}(C$. nov.)

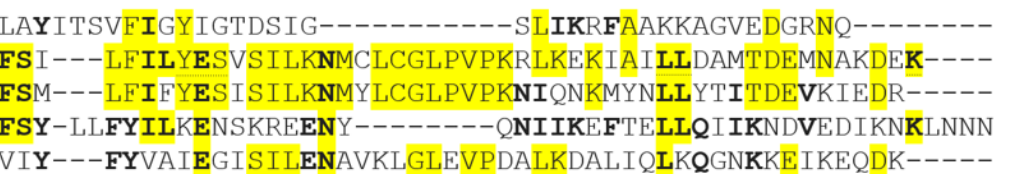

68

117

93

18

91
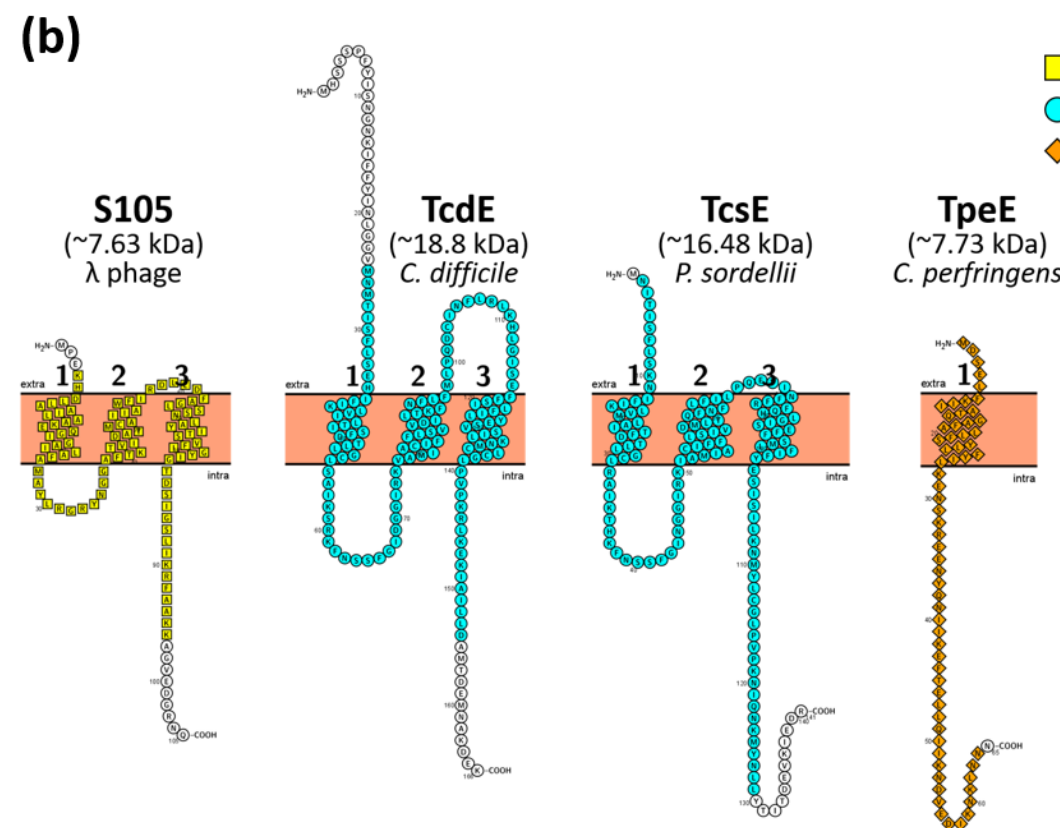

$\square$ pfam05106: Phage_holin_3_1

pfam05105: Phage_holin_4_1

$\diamond$ pfam10960: Holin_BhIA

Figure 2. Bioinformatic analysis of predicted holin proteins encoded by clostridial PaLoc regions. (a) Alignment of clostridial holin-like proteins from C. difficile (AJP10337), P. sordellii (CEJ75464), C. perfringens (CRG98304) and C. novyi type A (KEH84763) with $\lambda$ phage holin S105 (UniProtKB-P03705). Amino acids with identity to $C$. difficile TcdE are highlighted in yellow; those identical to C. perfringens TpeE are bolded. Constructed using Clustal Omega from the EMBL-EBI suite [33]. (b) Predicted membrane topology and conserved domains of clostridial holins. The predicted molecular weight in kDA is displayed for each holin. Cell membranes are represented as solid pink bars in which transmembrane domains (TMDs) are embedded. The number of TMD domains are shown in black. No signal peptides were predicted for any of the sequences. Amino acids that correspond to conserved protein domains are indicated as follows: yellow squares_-pfam05106 domain, Phage_holin_3_1; blue circles_pfam05105 domain, Phage_holin_4_1; orange diamonds_-pfam10960 domain, Holin_BhlA (found in a number of holin-like proteins of phage and bacterial origin. BhlA displays auto-lytic activity leading to bacterial cell death by membrane disruption) $[34,35]$. Figure constructed using Protter [36]. 


\subsection{TcsE, TpeE and TcnE Function Like TcdE as Holins}

We evaluated the holin-like activity of TcsE, TpeE, and TcnE by complementing an $E$. coli $\lambda$ lysogen defective for the $S^{105}$ holin with their respective encoding genes, as previously performed for TcdE and UviB [10,37]. The tcsE, tpeE, and tcnE genes were cloned into the heat-inducible expression plasmid $\mathrm{pBRQ}(\triangle \mathrm{RBS})$ and were introduced into E. coli MC1061 carrying the $\lambda$ lysogen ( $\mathrm{CI}_{857}$ Sam7), which has a functional endolysin gene but a nonsense mutation in its holin gene. When the $\lambda$ holin $S^{105}$ gene is used to complement the holin gene mutation in this strain, bacterial lysis is completed 45 min after heat induction (Figure 3a) since the presence of a functional holin allows the endolysin to cross the membrane and degrade murein from the outside, resulting in cell lysis. No lysis was observed in the presence of the vector alone (Figure 3a). When TcsE, TpeE, and TcnE were expressed in E. coli strain MC1061( $\left.\lambda \mathrm{CI}_{857} \mathrm{Sam7}\right)$, complete bacterial lysis was seen $\sim 45$ min after heat induction, similar to the positive control $\left(\lambda\right.$ holin $\left.S^{105}\right)$ and to TcdE (Figure 3a). Expression of TcsE, TpeE, and TcnE in the E. coli strain $\lambda \mathrm{Cmr} \Delta(S R)$, which has deletions in both the holin and endolysin genes, did not cause cell lysis (Figure $3 b$ ), confirming that lysis in the strain $\mathrm{MC} 1061\left(\lambda_{\mathrm{cI}} \mathrm{B57}_{7} \mathrm{Sam} 7\right)$ resulted specifically from holinfacilitated endolysin activity, demonstrating that these proteins function in the same way as a phage holin, similar to TcdE [10]. This finding also supports the role of TpeE as a holin protein [22], which, until now, had not been shown to complement holin functionality.

(a)

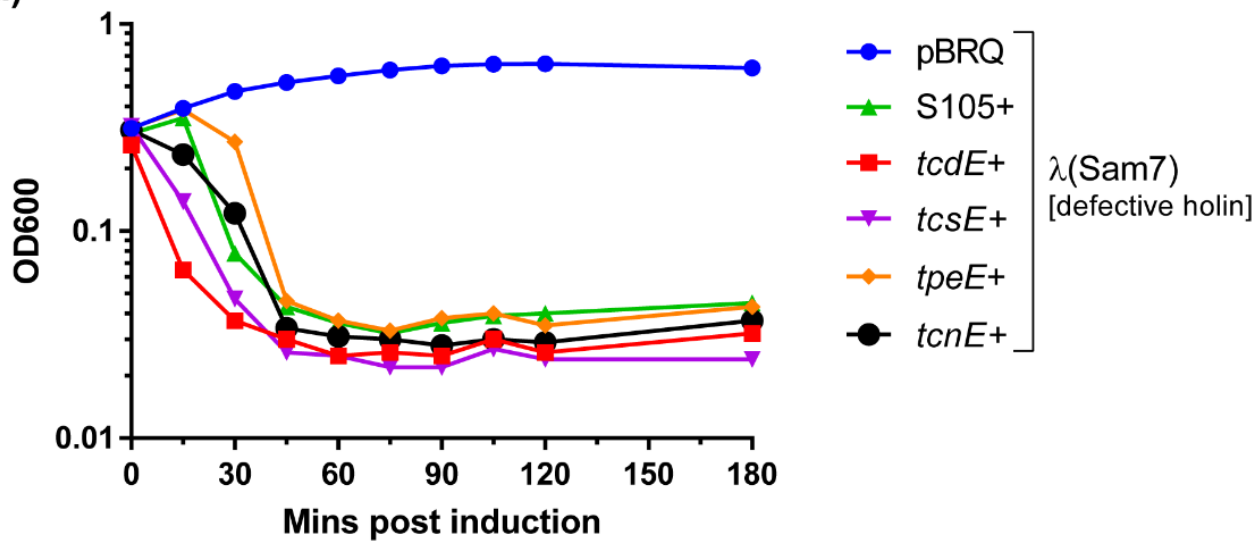

(b)

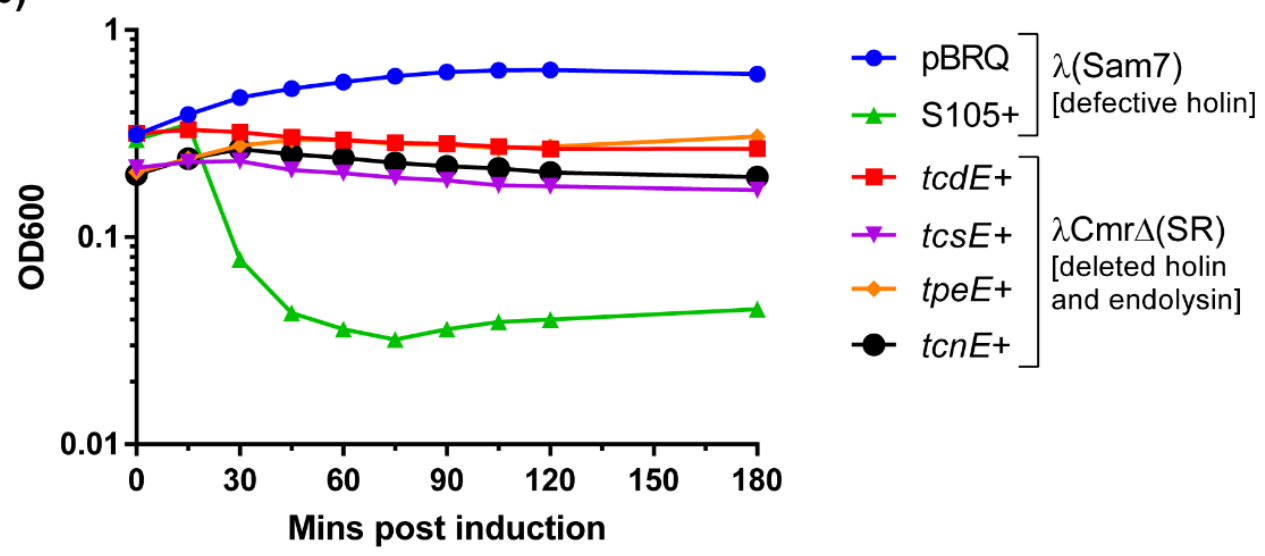

Figure 3. Determination of holin function of TcdE-like proteins in E. coli. Lysis curves after thermoinduction of lysogenic cultures of $E$. coli $\lambda \mathrm{cI}_{857} \operatorname{Sam} 7$ (a) or $E$. coli $\lambda \mathrm{Cmr} \Delta(S R)$ (b) carrying plasmids expressing TcdE, TcsE, TpeE, or TcnE in trans. A lysogenic strain carrying pJN5 encoding the $\lambda$ holin $\mathrm{S}^{105}$, and $\mathrm{pBRQ}(\triangle \mathrm{RBS})$ were used as positive and negative controls, respectively. The cultures were grown at $30{ }^{\circ} \mathrm{C}$ until $\mathrm{OD}_{600}=0.15-0.20$, thermoinduced for $5 \mathrm{~min}$ at $42{ }^{\circ} \mathrm{C}$, and then incubated at $37^{\circ} \mathrm{C}$, with $\mathrm{OD}_{600}$ measurements taken every $15 \mathrm{~min}$. 


\subsection{The Release of TcsL in P. sordellii Is Facilitated by the PaLoc-Encoded Holin TcsE}

To determine the roles of the PaLoc-associated holin gene in LCGT secretion, we focused on the role of TcsE in the secretion of TcsL. Two independent P. sordellii strain ATCC 9714 tcsE mutants were constructed using the TargeTron insertional inactivation system. The mutations were confirmed using PCR (data not shown) and Southern hybridisation (Figure S1) and were complemented in trans through the introduction of wild-type tcsE cloned in the clostridial vector pRPF185, under the control of a Tet inducible promoter. The wildtype, mutant, and complemented isogenic panel of strains were then tested for their ability to release TcsL. To do this, $P$. sordellii strains at the mid-exponential growth phase were diluted to a low optical density in TY broth (a media deficient in glucose, as the sugar is known to repress TcsL expression [32]) and grown for either 10 or $22 \mathrm{~h}$. At one hour and five hours into their growth, respectively, anhydrous tetracycline was added to all cultures to induce expression of the cloned genes in the complementation strains. At ten hours, cells were collected for extraction of RNA, followed by collection and filter sterilisation of the culture supernatant at $10 \mathrm{~h}$ and $22 \mathrm{~h}$ post inoculation.

TcsL levels were determined using a $C$. difficile TcdB-specific ELISA since the TcdB antibodies in this ELISA cross-react with TcsL (Figure S2). Both independent mutants of tcsE had $\sim 50 \%$ less TcsL in their supernatant fractions compared to the wild-type strain (Figure 4a), which was restored upon in trans complementation with wild-type tcsE, but not with the vector alone (Figure $4 \mathrm{a}$ ). These results showed a similar trend when the supernatants were tested at $10 \mathrm{~h}$; however, toxin levels at this time point were low (Figure S3). To validate that functional toxin was being released, a Vero cell cytotoxicity assay was performed using concentrated culture supernatants. This experiment confirmed that the toxin released was indeed functional and supports the results obtained with the ELISAs (Figure S4). Furthermore, the reduction in TcsL levels between strains did not result from any alterations in growth patterns (Figure $4 \mathrm{~b}$ ) or differences in tcsL expression (Figure 4c); thus, the holin-like protein TcsE appears to be required for the efficient release of TcsL from P. sordellii. Since TcsL is still detected in the supernatants of the tcsE mutants (Figure 4a), concomitantly to the cell lysis that is observed during the stationary growth phase (Figure $4 \mathrm{~b}$ ), this result suggests a co-existing lytic mechanism for LCGT release, as is observed for C. difficile [21].

\subsection{The TcsE Holin-like Protein Is Specific for TcsL Release Alone}

TcsE clearly plays a major role in the secretion of TcsL in P. sordellii, but it is not known if TcsE facilitates the release of any other proteins. To investigate this hypothesis, secretome samples of each of the tcsE isogenic panel of strains were collected (in four biological replicates per strain). This was achieved through harvesting the culture supernatants of the 22-h timepoint of each strain from the analysis represented in Figure 4, followed by enzymatic digest and collection of all peptides. The $22 \mathrm{~h}$ timepoint was chosen as the timepoint for analysis since TcsL levels are very low earlier in the growth phase, making differentiation of its secretion from other supernatant proteins difficult. 
(a)

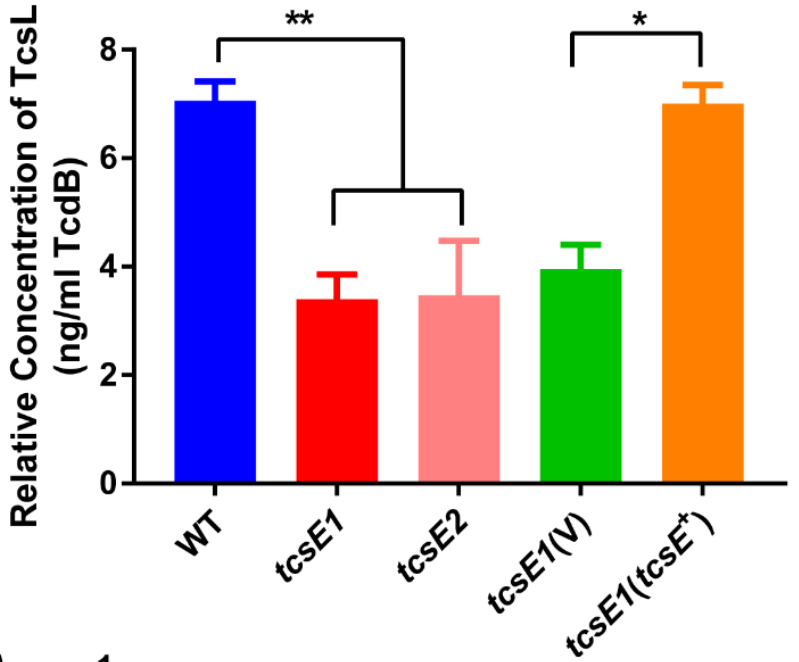

(b)

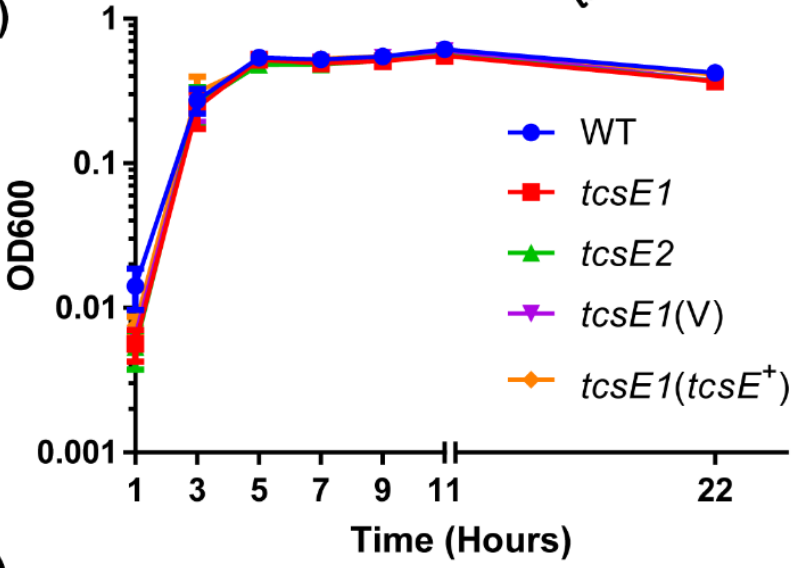

(c)

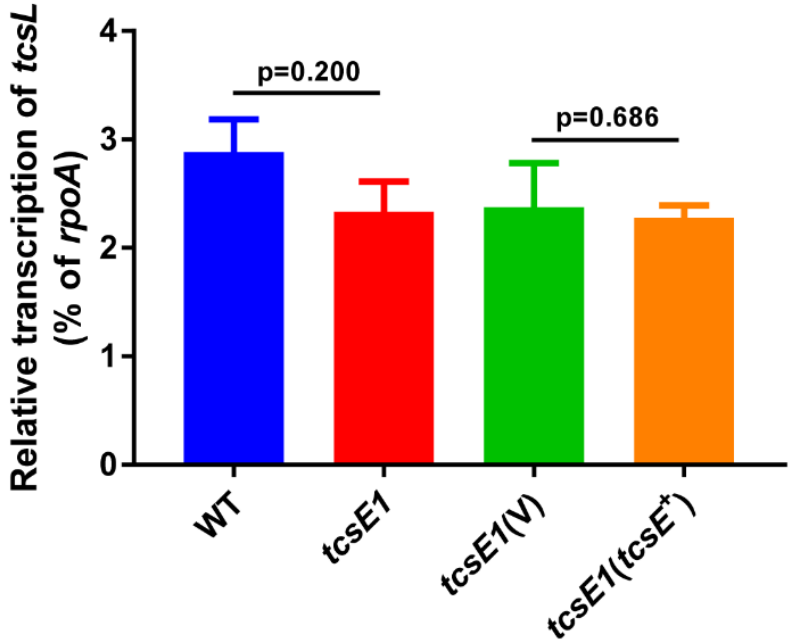

Figure 4. Analysis of TcsL secretion in a holin mutant of P. sordellii. (a) Levels of TcsL in the TY culture supernatant of the isogenic strains. At $\mathrm{T}=22 \mathrm{~h}$, culture supernatants were collected and assayed using a TcdB-specific ELISA detection kit (tgcBiomics). The concentrations of TcsL detected relative to a TcdB standard protein curve are shown, having been standardised to total protein concentration in the supernatant as determined by a BCA assay. $n \geq 4$, error bars indicate SEM. Statistical analysis was conducted using a Mann-Whitney $U$ Test ${ }^{*} p<0.05,{ }^{* *} p<0.01$. (b) Growth curve of the TY cultures over $22 \mathrm{~h}$. After dilution in TY broth, an $\mathrm{OD}_{600}$ reading was taken at $\mathrm{T}=1$, followed by every $2 \mathrm{~h}$ until $\mathrm{T}=11$. A final reading was taken at $\mathrm{T}=22$. $\mathrm{n} \geq 3$, error bars indicate SEM. (c) Relative levels of 
tcs $L$ transcription among the isogenic panel of mutants. At $\mathrm{T}=10 \mathrm{~h}$, cells were collected from TY cultures; RNA was extracted and cDNA synthesized. Concentrations of $t c s L$ and $r p o A$ (housekeeping control) transcript were determined from the cDNA using ddPCR. Displayed is the relative expression of $t c s L$ as a percentage of $r p o A$ (housekeeping gene) expression for each mutant. $\mathrm{n}=4$, error bars indicate SEM. Statistical analysis was conducted using a Mann-Whitney $U$ Test.

Proteins were identified using mass spectrometry, and their levels determined by label-free quantification. Proteins were included in the analysis if two unique peptides were detected in at least three biological replicates of one of the four test strains. In total, 9 out of the total 802 proteins were identified to have significantly altered levels in the culture supernatant from the tcsE mutant based on a false discovery ratio of 0.1 with 250 permutations combined with a within-group variance cutoff of 0.1 (Table 1 , represented as red circles in Figure 5a). This cutoff was chosen due to a likelihood of lysed cell cytoplasm components partially clouding secretion profiles, is represented as black curves in Figure 5, and equates approximately a $p$-value cutoff of $>0.01$ combined with an approximate fold increase greater than 2 (positive or negative) between means. Proteins with reduced abundance were represented by the toxin TcsL, a probable polysaccharide-deacetylase, a phospholipase D-nuclease domain protein, and a group of protein constituents from the $50 S$ ribosome (Table 1a). However, the vast majority of predicted cytoplasmic proteins identified via mass spectrometry (File S1, Figure 5a) were not significantly altered between the WT and tcsE mutant strains; therefore, we suggest that differences between these strains are unlikely to be due a general lytic mechanism of TcsL release.

To confirm the role of $t c s E$ in the differential release of these nine proteins, the secretome of the complemented tcsE mutant was compared to the vector control of the tcsE mutant (Figure $5 b$ ). In this comparison, 13 proteins were determined to be significantly altered in abundance (Figure 5b, Table 1b), using the same statistical/foldchange cutoff. However, TcsL was the only protein to be significantly altered in both comparisons (Table 1, Figure 5), displaying a $\sim 50 \%$ reduction in the $t c s E$ mutant in comparison to the wild-type strain, which was restored upon complementation (Table 1, Figure 5). We suggest that the remaining 8 proteins identified from the $\mathrm{M}$ vs. WT and 12 proteins from the $\mathrm{C}$ vs. VC (Table 1) comparisons were aberrations introduced by unrelated factors such as minor differences in growth and lytic release of proteins unrelated to TcsE. Of these 20 proteins, only three display $p$-values that could be considered significantly different between comparisons (both $p<0.05$ ), those being the phospholipase D nuclease domain protein from the first comparison (Table 1a), the putative delta-lactam-biosynthetic de-N-acteylase, and a conserved hypothetical protein from the second (Table 1b). If the difference in the proteins levels between treatments was truly due to the presence/absence of TcsE, we would expect a reciprocal pattern when comparing the mutant to the wildtype of that when comparing the vector control to the complemented strain (e.g., a decrease vs. an increase). However, the differences in these three proteins are unlikely to be due to the action of TcsE, as they are not reciprocal in their abundance between the WT vs. MT and the C vs. VC comparison. They are either increased in both the mutant and the complemented strain, or they are both reduced in abundance, suggesting that the presence of TcsE is not controlling any differences in abundance. As TcsL is the only protein that appeared in the cutoff in both comparisons (Table 1, Figure 5) and displays a reciprocal pattern between the M vs. WT and V vs. VC comparisons ( 0.48 vs. 2.25 , Table 1$)$, we suggest that the TcsE-mediated secretion of TcsL is specific, being the only protein released by this holin-like protein under both conditions tested. 
Table 1. Proteins significantly altered in quantity between the culture supernatants of (a) tcsE mutant (M) and wildtype (WT) P. sordellii ATCC9714 strains and (b) complemented tcsE mutant (C) and the tcsE mutant vector control (VC) P. sordellii ATCC9714 strains.

\begin{tabular}{|c|c|c|c|c|c|c|c|}
\hline \multicolumn{2}{|l|}{ (a) } & \multicolumn{3}{|c|}{ M vs. WT } & \multicolumn{3}{|c|}{ C vs. VC } \\
\hline Protein & Protein ID & Fold Change & $\begin{array}{l}p \text {-Value } \\
\left(\times 10^{-3}\right)\end{array}$ & q-Value & Fold Change & $\begin{array}{l}p \text {-Value } \\
\left(\times 10^{-3}\right)\end{array}$ & q-Value \\
\hline 50 S ribosomal protein L31 & CEJ72251.1 & 0.12 & 0.180 & 0.224 & 0.70 & 541 & 0.679 \\
\hline 50 S ribosomal protein L24 & CEJ72165.1 & 0.38 & 0.847 & 0.126 & 1.06 & 648 & 0.836 \\
\hline TcsL-Lethal Toxin & CEJ75463.1 & 0.48 & 0.641 & 0.111 & 2.25 & 1.73 & 0.147 \\
\hline $50 S$ ribosomal protein L5 & CEJ72166.1 & 0.51 & 1.17 & 0.103 & 0.96 & 779 & 0.896 \\
\hline $\begin{array}{c}\text { probable polysaccharidede } \\
\text { acetylase }\end{array}$ & CEJ75226.1 & 0.51 & 1.41 & 0.104 & 0.90 & 626 & 0.802 \\
\hline 50 S ribosomal protein L10 & CEJ72145.1 & 0.53 & 1.27 & 0.092 & 0.80 & 314 & 0.547 \\
\hline $50 S$ ribosomal protein L22 & CEJ72159.1 & 0.54 & 0.122 & 0.131 & 0.79 & 200 & 0.435 \\
\hline $50 \mathrm{~S}$ ribosomal protein $\mathrm{L} 4$ & CEJ72155.1 & 0.62 & 0.340 & 0.106 & 0.66 & 152 & 0.353 \\
\hline $\begin{array}{l}\text { phospholipase D-nuclease } \\
\text { domain protein }\end{array}$ & CEJ72911.1 & 4.69 & 0.967 & 0.170 & 2.47 & 26.2 & 0.158 \\
\hline \multicolumn{2}{|l|}{ (b) } & \multicolumn{3}{|c|}{ C vs. VC } & \multicolumn{3}{|c|}{ M vs. WT } \\
\hline Protein & Protein ID & Fold Change & $\begin{array}{l}p \text {-Value } \\
\left(\times 10^{-3}\right)\end{array}$ & $\mathrm{q}$-Value & Fold Change & $\begin{array}{l}p \text {-Value } \\
\left(\times 10^{-3}\right)\end{array}$ & $\mathrm{q}$-Value \\
\hline $\begin{array}{l}\text { spore coat peptide assembly } \\
\text { protein CotJC2 }\end{array}$ & CEJ72697.1 & 2.07 & 1.586 & 0.136 & 0.91 & 753 & 0.913 \\
\hline TcsL-Lethal Toxin & CEJ75463.1 & 2.25 & 1.731 & 0.147 & 0.48 & 0.641 & 0.111 \\
\hline $\begin{array}{l}\text { branched-chain amino acid } \\
\text { aminotransferase }\end{array}$ & CEJ74628.1 & 2.29 & 3.446 & 0.092 & 0.94 & 560 & 0.896 \\
\hline $\begin{array}{c}\text { putative } \\
\text { delta-lactam-biosynthetic } \\
\text { de-N-acteylase }\end{array}$ & CEJ73318.1 & 2.37 & 3.296 & 0.123 & 2.44 & 5.69 & 0.138 \\
\hline $\begin{array}{l}\text { putative } \\
\text { ferredoxin/flavodoxinoxido } \\
\text { reductase, alpha subunit }\end{array}$ & CEJ75209.1 & 2.48 & 1.890 & 0.169 & 0.95 & 702 & 0.914 \\
\hline $\begin{array}{l}\text { putative pyridine } \\
\text { nucleotide-disulphide } \\
\text { oxidoreductase }\end{array}$ & CEJ73686.1 & 2.62 & 4.003 & 0.111 & 1.09 & 653 & 0.899 \\
\hline $\begin{array}{l}\text { dimethylamine corrinoid } \\
\text { protein }\end{array}$ & CEJ74389.1 & 2.77 & 0.808 & 0.131 & 2.50 & 132 & 0.643 \\
\hline $\begin{array}{l}\text { putative } \\
\text { ferredoxin/flavodoxinoxido } \\
\text { reductase, beta subunit }\end{array}$ & CEJ75208.1 & 2.86 & 4.135 & 0.139 & 1.15 & 402 & 0.896 \\
\hline hypothetical protein & CEJ73866.1 & 3.77 & 0.002 & 0.068 & 1.23 & 639 & 0.881 \\
\hline Chorismite mutase & CEJ73786.1 & 4.10 & 7.106 & 0.085 & 0.82 & 776 & 0.914 \\
\hline conserved hypothetical protein & CEJ72332.1 & 5.12 & 0.711 & 0.138 & 3.47 & 14.7 & 0.185 \\
\hline hypothetical protein & CEJ74906.1 & 6.91 & 8.456 & 0.101 & 1.40 & 766 & 0.911 \\
\hline $\begin{array}{c}\text { ureE urease accessory, } \\
\text { N-terminal domain protein }\end{array}$ & CEJ73734.1 & 6.93 & 1.349 & 0.132 & 0.88 & 571 & 0.892 \\
\hline
\end{tabular}

The proteins and their protein ID accession numbers are listed in the order of fold change. Given are the average fold change, $p$-value, and q-value determined by a two-tailed student $t$-test of $\log _{2}$ transformed intensity values, obtained by mass spectrometry-based label-free protein quantification. The value for the comparison of the (a) complemented $t c s E$ mutant (C) to the $t c s E$ mutant containing the vector control (VC), or (b) tcsE mutant (M) to the wildtype (WT), for these proteins is also provided. The only protein identified to be altered in both comparisons, and its corresponding values, is shown in bold. 
(a) tcsE1 vs WT

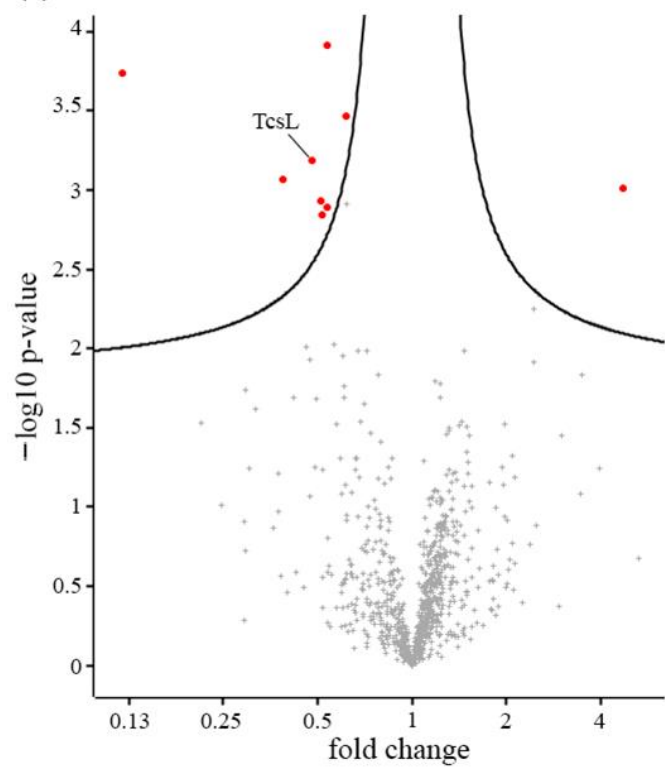

(b) $t c s E 1(t c s E+)$ vs $t c s E 1(\mathrm{~V})$

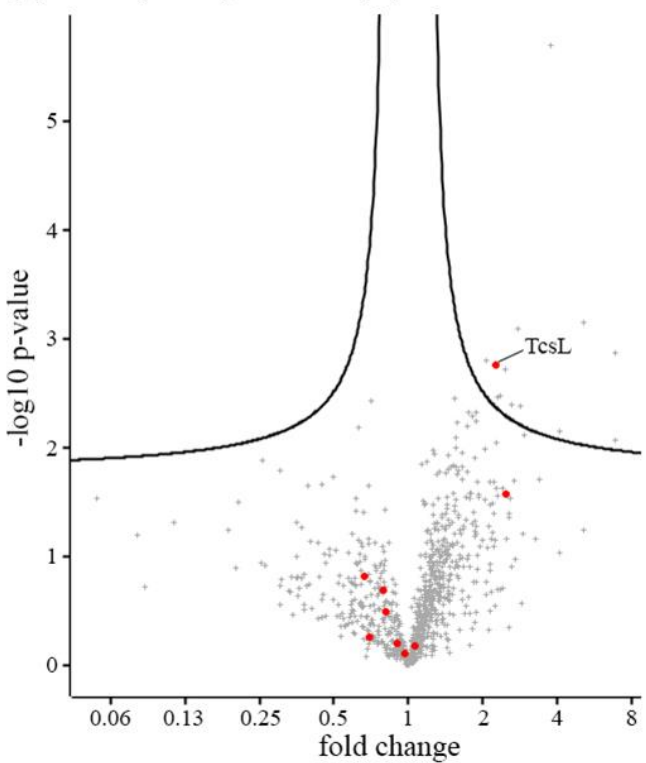

Figure 5. Secretome analysis of the tcsE holin mutant of $P$. sordellii. Shown are volcano plots representing a label-free quantification nLC-MS/MS analysis, comparing the abundance of individual proteins in the culture supernatant of wild type (WT) P. sordellii ATCC9714 with an isogenic tcsE mutant (a), as well as comparing the complemented $t c s E$ mutant against the same mutant carrying the control vector pRPF185 (b). Each data point represents an individual protein detected in the supernatant. The $\mathrm{x}$-axis displays the fold change between the means of the two strains. The $\mathrm{y}$ axis displays the $-\log 10$ of the $p$-value from a 2-tailed student's $t$-test on $\log 2$ transformed values. The threshold for significance was determined as a permutation-based false discovery ratio of 0.1 combined with an artificial within group's variance of 0.1 using 250 randomisations, which is represented as the black curves on the chart. The nine proteins that have significantly different levels in the supernatant between the WT and the mutant are shown as red circles on both plots.

\section{Discussion}

The best-understood bacterial secretion systems in monoderm organisms, such as Tat and Sec, are highly specific, with amino acid signals within the secreted proteins being recognised by an export machinery for transport out of the bacterial cell [2]. In addition to these signal peptide-driven secretion machineries, recent studies have suggested that unrelated secretion systems function to export a diverse range of products made within bacterial cells. One of these systems consists of one or two components, a holin and/or an endolysin [10,30,38,39]. These systems, however, are not well accepted as specific secretion systems, partly because substrate specificity has not been clearly demonstrated, and because they are thought to facilitate protein secretion through a generalised cell lysis mechanism [27]. The work presented here definitively shows that at least a component of one such system, mediated by the $P$. sordellii holin TcsE, functions to export TcsL and that the release of this toxin occurs independently of other bacterial proteins, suggesting that TcsL is the only protein dependent on this export system for its release in its natural host.

In $C$. difficile, using almost identical strains, the holin-like protein TcdE was shown to mediate the release of the LCGTs TcdA and TcdB in one study [10], but another study suggested that TcdE was not involved in this phenotype [40]. Recent work has clarified the difference between the two earlier studies by proposing that two distinct processes are involved in LCGT release in C. difficile strain 630 according to the in vitro medium used. The first of these is a lytic mechanism controlled by the lytic transglycosylase Cwp19 and is most evident in glucose-containing BHI media and during later growth stages, while the second is a non-lytic mechanism controlled by TcdE, which is responsible for toxin release in earlier growth stages and in TY medium without glucose [21]. The more recent finding that 
the mutagenesis of $t c d E$ in a different strain background reduced LCGT release provided further support for the role of TcdE in LCGT secretion [39]. However, the role of TcdE in toxin secretion continues to be debated because a mechanism by which a holin could release large proteins such as TcdA (308 kDa) and TcdB $(270 \mathrm{kDa})$ is not apparent [27,41].

Here, we have shown that, similar to $C$. difficile, the PaLoc regions in other pathogenic clostridia such as $P$. sordellii, $C$. perfringens, and $C$. novyii encode a functional holin-like protein, although secretion via a holin-like protein was also shown for C. perfringens in a recent study [22]. We also show that the $P$. sordellii holin-like protein TcsE is clearly required for the efficient release of the toxin in strain ATCC 9714 (Figure 4a). While a lytic mechanism did also appear to partially release TcsL, the TcsE-mediated mechanism was unlikely to involve lysis, since no growth differences were detected between the relevant $t c s E$ mutants when compared to the wild-type strain (Figure $4 \mathrm{~b}$ ). Therefore, while a specific TcsE-mediated pathway may be required for efficient TcsL release, it may be that an additional unrelated lytic mechanism is required to release enough TcsL. This additional lytic mechanism may be similar to that observed in C. difficile due to the protein Cwp19 [21], supported by the presence of proteins also with GHL10 (pfam02638) domains encoded on the chromosome (CEJ74920.1 in ATCC9714). These data suggest that the TcsE-mediated release of TcsL is a specific process, which was supported by results showing that there were no significant changes in the levels of the vast majority of cytoplasmic proteins identified in the secretomes of the tcsE mutant compared to the wild-type strain (Figure $5 \mathrm{a}, \mathrm{b}$ ). TcsL may not be the sole protein able to be secreted by TcsE, since the release of a $\lambda$ phage endolysin, across the plasma membrane, was observed using an E. coli holin complementation system (Figure 3). However, in its natural host, TcsL appears to be the only protein that was significantly reduced in culture supernatants when TcsE is absent and is subsequently more abundant upon complementation of the tcsE mutation (Figure 5).

TcdE and, more recently, TpeE, which has been shown to mediate C. perfringens TpeL secretion independently of cell lysis [22], are perhaps the best studied of these secretionrelated bacterial holin-like proteins. However, other studies have examined the role of bacterial holins in protein secretion. Among them, a holin-like protein, ChiW, appears to be required for the release of chitinases in $S$. marcescens. In fact, deletion of the encoding gene significantly reduced the release of three chitinases, a chitinase binding protein and at least six other proteins, although not all were confirmed by complementation [30]. Interestingly, it was noted that a cognate endolysin, ChiX, encoded within the same phage lysis-like locus, was also required for the release of these chitinases [30]. When ChiX was fused to a Tat signal peptide, thereby bypassing the need for holin-mediated translocation of the CM, the holin gene mutant was effectively complemented [30], indicating that the endolysin is the main facilitator of protein secretion, and that the holin is simply required to translocate the endolysin into the periplasmic space [30]. A non-phage associated endolysin-like protein, TtsA, also seems to control the release of typhoid toxin from Salmonella Typhi cells [38]. Recent work has shown that TstA is responsible for the transfer of Typhoid toxin from the cis to the trans side of the peptidoglycan, a process that, in turn, requires peptidoglycan remodelling by a cognate LD-transpeptidase [42]. In both of these examples, the endolysinmediated release of proteins does not appear to be lytic. Instead, it was postulated that the endolysin functions to remodel the peptidoglycan within the cell wall to allow for the efficient transfer of specific proteins through the periplasm [30,38,42]. Whether an endolysin is required for the efficient release of the LCGTs from the clostridia is still a subject of debate.

It has been suggested that large proteins, such as LCGTs, are unlikely to be translocated via a holin alone. In fact, to do so, the holin would have to either actively transport these proteins or make a pore so large that cytoplasmic leakage or cell lysis would occur [27], although if toxins were transferred in an unfolded state, this leakage would be minimised. However, holins do not contain ATP-hydrolysis motifs, nor do the majority appear to function using proton-motive force $[23,27]$. The mechanism proposed by Saadat and Melville for TpeE-specific release of TpeL is a charged zipper mechanism, in which a 
cytoplasmic amphipathic helix on TpeE is activated by the insertion of a hydrophobic patch on TpeL, which then oligomerizes around TpeL to allow passage through the membrane. A high charge density domain at the C-terminus of TpeE (KNKLNNN) then acts to stabilise this confirmation [22]. While each of the other LCGTs also contain a hydrophobic patch that may initiate this system, an amphipathic helix is not predicted at the C-terminus of TcdE or TcsE [22]. This may mean that, while also requiring holin proteins for efficient secretion of LCGTs, the mechanism by which this is achieved differs between $C$. perfringens and the other clostridia.

The specific mechanism of secretion of these LCGTs is still up for debate and requires further investigation. It may be that the holin-like protein is responsible for the release of an intermediary protein that provides specificity for release. This intermediary protein may come in the form of an endolysin that remodels the peptidoglycan to allow the transit of such a large protein, as has been suggested in S. marcescens and Salmonella Typhi $[30,38,42]$. This hypothesis is consistent with the presence of endolysin-encoding genes in the PaLoc of $P$. sordellii and in some strains of $C$. difficile $[37,43]$. In this model, the specificity of release for TcsL that occurs in the presence of TcsE (Figure 5, Table 1) would be indirect, with TcsE required to specifically translocate an endolysin required to act and then facilitate the translocation of TcsL across the P. sordellii cell wall. However, this would still not address how the toxin is able to translocate across the cellular membrane. Alternatively, some version of the charged zipper mechanism suggested for TpeE/L may also be seen in the other Clostridia [22], where the insertion of the hydrophobic patch of the LCGT in the cell membrane is the trigger for oligomerisation around the toxin, preventing disruption of the proton motive force and resultant lysis from such a large pore. This explanation provides a pathway for a non-lytic, specific translocation of LGCTs across the cellular membrane. This model would also provide specificity of TcsE for TcsL, as suggested by our findings (Figure 5, Table 1), where it is the translocation across the cytoplasmic membrane that TcsE is required for and plays a direct role in. Regardless, the studies presented here suggest that TcsE-mediated secretion is specific for TcsL alone in P. sordellii, and that the S. marcescens ChiW and C. difficile TcdE systems also demonstrate some level of specificity [10,30], which means that cell lysis is probably not the release mechanism involved in these established holin-mediated systems [10].

Further analysis of LCGT secretion is therefore required. These studies will facilitate a deeper understanding of non-phage-associated holin-mediated secretion, which requires further investigation since they have been identified on the chromosomes of many Gramnegative and Gram-positive bacteria, as well as in archaea and eukaryotic organisms [24]. The specificity observed in the holin-mediated toxin release of TcsL from P. sordellii, detailed here, strongly supports the proposal of the existence of a new type of secretion system [44].

\section{Materials and Methods}

\subsection{Bacterial Strains and Culture Conditions}

Table S1 lists bacterial strains used in this analysis. Unless stated otherwise, clostridial species were cultured in HIS broth (37 g/L heart infusion broth (Oxoid), $5 \mathrm{~g} / \mathrm{L}$ yeast extract, $1 \mathrm{~g} / \mathrm{L}$ L-cysteine, $0.375 \%$ (wt/vol) glucose) or on HIS agar (HIS broth with $15 \mathrm{~g} / \mathrm{L}$ agar) at $37^{\circ} \mathrm{C}$ in an anaerobic chamber (Coy Laboratory Products, Inc., Grass Lake, MI, USA) in an atmosphere of $10 \% \mathrm{H} 2,10 \% \mathrm{CO} 2$, and $80 \% \mathrm{~N} 2$. E. coli strains were grown with shaking at $200 \mathrm{rpm}$ in $2 \mathrm{YT}_{\text {broth }}(16 \mathrm{~g} / \mathrm{L}$ tryptone, $10 \mathrm{~g} / \mathrm{L}$ yeast extract, $5 \mathrm{~g} / \mathrm{L} \mathrm{NaCl})$ or on $2 \mathrm{YT}$ agar (2YT broth with $15 \mathrm{~g} / \mathrm{L}$ agar) at $37^{\circ} \mathrm{C}$. When required, the following antibiotics were included for selection: erythromycin $(10 \mathrm{mg} / \mathrm{L})$, chloramphenicol $(25 \mathrm{mg} / \mathrm{L})$, thiamphenicol (10 mg/L), and lincomycin (50 mg/L).

\subsection{Bioinformatic Analysis}

Sequences representing the clostridial PaLocs and associated genome sequences were obtained from GenBank [45], with primary accession numbers for each sequence as follows: C. difficile 630 [46]: CP010905, P. sordellii ATCC 9714 [47]: LN679999, P. sor- 
dellii JGS6382 [47]: LN681235, C. perfringens JIR12708 [48]: LN835295 and C. novyi (A) BKT29909 [49]: JENM01000095. The sequences were further manually annotated using Artemis [50] on the basis of homology to entries in the Pfam database [35] via the HMMSCAN search on the HMMER web server [51]. The prediction of signal peptides and transmembrane domains within predicted amino acid sequences was performed using the Phobius web server [52] and confirmed using SignalP 4.1 [53]. Protein molecular weights were determined using SnapGene Viewer (from GSL Biotech; available at snapgene.com, accessed on 28 January 2022). The clostridial PaLocs were aligned, and the resulting graphics were produced using EasyFig [26]. Multiple sequence alignments were conducted using Clustal Omega from EMBL-EBI tools [54].

\subsection{TcdE-like Holin Activity Assay}

The tpeE, tcsE, and $t c n E$ genes, including their own ribosomal binding site (RBS), were amplified by PCR (Table S2), digested and ligated to $\mathrm{pBRQ}(\triangle \mathrm{RBS})$, a derivative of $\mathrm{pJN} 4$ deleted in the RBS of the $\lambda S$ gene [17]. To test the holin activity of the TcdE-like proteins, lysogens of $E$. coli strain MC1061 for a defective $\lambda$ prophage bearing a nonsense mutation in its holin gene [ $\left.\lambda_{\mathrm{Cl}} \mathrm{S}_{57} \mathrm{Sam} 7\right]$ or carrying a deletion in holin and endolysin genes $\left[\lambda \mathrm{Cm}^{\mathrm{r}} \Delta(S R)\right]$ were used as hosts for the plasmid constructs. These plasmids included pJN5, carrying the gene encoding the $\lambda$ holin S105, and $\mathrm{pBRQ}(\triangle \mathrm{RBS})$, used as positive and negative controls, respectively. Both $\lambda(\mathrm{Sam} 7)$ and $\lambda \mathrm{Cm}^{\mathrm{r}} \Delta(\mathrm{SR})$ encode a thermo-sensitive $\mathrm{CI}$ repressor (cI ${ }_{857}$ ) and are induced upon shifting the culture temperature from $30^{\circ} \mathrm{C}$ to $42^{\circ} \mathrm{C}$. Strains were grown in $\mathrm{LB}$ broth at $30^{\circ} \mathrm{C}$ until the $\mathrm{OD}_{600}$ reached $0.15-0.25$ before the thermo-induction of the $\lambda$ prophage at $42{ }^{\circ} \mathrm{C}$ for $15 \mathrm{~min}$. Bacterial growth and lysis at $37^{\circ} \mathrm{C}$ were then followed by monitoring the absorbance at $600 \mathrm{~nm}$ at $15 \mathrm{~min}$ intervals. The curves in Figure 3 are a compilation of five independent cultures.

\subsection{Mutagenesis}

Mutagenesis using the TargeTron system and subsequent complementation was performed using a published method [55]. For mutagenesis, group II intron was retargeted to insert at the following distances from the predicted start of the coding sequence: between $161 / 162 \mathrm{bp}$ of the anti-sense strand for ATCC 9714 tcsE, based on predictions from the Perutka Algorithm [56] via the ClosTron [57] design tool (http:/ / clostron.com/clostron2.php, accessed on 10 March 2017). The correct insertion of the intron and the loss of the plasmid were confirmed using PCR and Southern hybridisation as previously described [55]. Primers used for PCR detection and probe generation in this study are listed in Table S2. TcsL TT mutant (DLL5002) referred to in the Supplementary Material was constructed as part of a previous study [58]. Similarly, the pCS1 plasmid-free P. sordellii strain referred to in the Supplementary Material was derived in a previous study, having lost the plasmid due to a targetron inactivation of the parB plasmid partitioning gene, followed by subculture [55].

\subsection{Complementation in Trans}

For complementation, genes including their RBS were PCR amplified using ATCC9714 genomic DNA as a template, with primers DLP525 and DLP526 for tcsE. PCR products were cloned into pRPF185 using restriction enzymes BamHI and SacI. The relevant primers are listed in Table S2.

\subsection{TcsL Release Assays}

Mid-logarithmic phase P. sordellii cultures in HIS broth were diluted to an $\mathrm{OD}_{600}$ of 0.3 before a $1 / 100$ dilution into $20 \mathrm{~mL}$ TY ( $30 \mathrm{~g} / \mathrm{L}$ tryptone, $20 \mathrm{~g} / \mathrm{L}$ yeast extract) broth in tissue culture flasks. The TY cultures were incubated for $22 \mathrm{~h}$ at $37^{\circ} \mathrm{C}$ in an anaerobic environment. At $\mathrm{T}=5 \mathrm{~h}$, anhydrous tetracycline $(50 \mathrm{ng} / \mathrm{mL})$ was added to all cultures to induce the complementation vectors. At $\mathrm{T}=10 \mathrm{~h}$, cells were collected and RNA extracted for transcript analysis. At $\mathrm{T}=10 \mathrm{~h}$ and $\mathrm{T}=22 \mathrm{~h}$, culture supernatants were collected by pelleting cells by centrifugation at $2500 \times g$, followed by filtering the supernatant through 
a 0.22-micron filter to remove all bacterial cells. The supernatants were analysed for TcsL levels using a C. difficile TcdB-specific ELISA detection kit (tgcBiomics), which is crossreactive to TcsL (Figure S2), following the manufacturer's instructions. TcsL levels were standardised to total protein based on a BCA assay (Thermo Scientific, Scoresby, Australia) and are presented relative to a TcdB standard curve. Statistical analysis was carried out using the Mann-Whitney $U$ test on $\geq 4$ independent biological replicates.

\subsection{Vero Cell Cytotoxicity Assay}

To prepare supernatants for cell cytotoxicity assays, $P$. sordellii was grown in $100 \mathrm{~mL}$ of TY broth with a starting optical density at $600 \mathrm{~nm}$ (OD600) $\mathrm{nm}$ of 0.05 , for $24 \mathrm{~h}$, and the cells pelleted by centrifugation. The supernatants were filter sterilized through $0.22 \mu$ filters and stored at $4{ }^{\circ} \mathrm{C}$ prior to use. Cells were cultured in minimum essential medium (MEM alpha medium; GIBCO, Invitrogen, Scoresby, Australia) containing 10\% heat-inactivated fetal calf serum (HI FCS), 100 units $/ \mathrm{mL}$ penicillin, and $100 \mu \mathrm{g} / \mathrm{mL}$ streptomycin in culture flasks at $37^{\circ} \mathrm{C}$ in $5 \% \mathrm{CO} 2$. The cells were grown to a confluent monolayer and then sub-cultured by incubating in $2 \mathrm{~mL}$ of $0.1 \%$ trypsin in $1 \mathrm{mM}$ EDTA. The cells were counted and resuspended in fresh medium at a concentration of $1 \times 10^{5}$ cells $/ \mathrm{mL}$, and $100 \mu \mathrm{L}$ aliquots of the cell suspension were seeded into each well of 96 -well plates. The plates were then incubated for $20 \mathrm{~h}$, followed by the removal of the culture medium. Serial two-fold dilutions of the P. sordellii culture supernatants were prepared in MEM alpha medium supplemented, with $1 \%$ HI FCS and $100 \mu \mathrm{L}$ added to each well. Negative controls, which were cells treated with $100 \mu \mathrm{L}$ MEM alpha medium supplemented with 1\% HI FCS, were included. Plates were then incubated at $37^{\circ} \mathrm{C}$ in $5 \%$ CO2 and morphological changes observed via microscopy after $24 \mathrm{~h}$. The endpoint was scored as the last dilution at which a cytopathic effect (CPE) was observed.

\subsection{Growth Curves}

Mid-logarithmic phase P. sordellii cultures in HIS broth were diluted to an $\mathrm{OD}_{600}$ of 0.3 before a $1 / 100$ dilution into $20 \mathrm{~mL}$ TY broth in glass bottles. The TY cultures were incubated for $22 \mathrm{~h}$ at $37^{\circ} \mathrm{C}$ in an anaerobic environment. The $\mathrm{OD}_{600}$ of the cultures was recorded every two $h$ from $\mathrm{T}=1$ to $\mathrm{T}=11$, with a final reading at $\mathrm{T}=22$.

\subsection{Gene Expression Analysis}

Total P. sordellii RNA was obtained from $3 \mathrm{~mL}$ of TY broth culture at $\mathrm{T}=10$ of the TcsL release assay, equating to an early stationary growth phase. RNA was isolated and its concentration determined using a published method [59]. The expression of tcsL in P. sordellii was determined by reverse-transcriptase digital droplet PCR (RT-ddPCR) based on a previous protocol [59]. All reactions were conducted as per the manufacturer's (BioRad) instructions. Briefly, $200 \mathrm{ng}$ of total RNA was converted to cDNA using $100 \mathrm{ng}$ of random primers (Promega) and SuperScript ${ }^{\circledR}$ III reverse transcriptase (Invitrogen). PCR samples were set up to contain $5 \mathrm{ng}$ or $0.5 \mathrm{ng}$ of cDNA with genespecific primers at $200 \mathrm{nM}$ each, along with an equal volume of QX200 ${ }^{\mathrm{TM}} \mathrm{ddPCR}^{\mathrm{TM}}$ EvaGreen Supermix (BioRad, South Granville, Australia). PCR reactions were converted to droplets in DG8 ${ }^{\mathrm{TM}}$ cartridges (Bio-Rad) using the QX200 ${ }^{\mathrm{TM}}$ droplet generator (Bio-Rad) and amplified in a C1000 Touch ${ }^{\mathrm{TM}}$ thermal cycler (Bio-Rad). Amplification events within individual droplets were measured by the QX200 ${ }^{\mathrm{TM}}$ droplet reader (Bio-Rad), and the resulting data were analysed using QuantaSoft ${ }^{\mathrm{TM}}$ software (Bio-Rad). tcsL expression levels represent the number of transcripts per ng of cDNA, as a percentage of the transcripts of the housekeeping gene $r p o A$. Statistical analysis was carried out using the Mann-Whitney $U$ test on four independent biological replicates.

\subsection{Tryptic Digestion of Culture Supernatant Proteins}

To concentrate $P$. sordellii secreted proteins, ice-cold $100 \%(w / v)$ tri-chloroacetic acid was added to $1 \mathrm{~mL}$ aliquots of filtered culture supernatant to achieve a final concentration 
of $10 \%(v / v)$. The supernatants were left on ice overnight, and precipitated proteins were then pelleted at $17,000 \times g$ for $30 \mathrm{~min}$ at $4{ }^{\circ} \mathrm{C}$. The pellets were washed twice in $1 \mathrm{~mL}$ of $-20{ }^{\circ} \mathrm{C} 90 \%(v / v)$ acetone by incubation on ice for $15 \mathrm{~min}$ followed by centrifugation for $30 \mathrm{~min}$ at $4^{\circ} \mathrm{C}$. All remaining acetone was removed, and protein pellets were air-dried in a fume hood for $10 \mathrm{~min}$ and then stored at $-80^{\circ} \mathrm{C}$ until needed.

Proteins were resuspended in $100 \mu \mathrm{L} 1 \times$ LDS buffer (Thermo Fisher Scientific). The concentration of total protein $(>10 \mathrm{kDa})$ in each sample was determined using densitometry. To do this, samples were separated by SDS-PAGE in a $4-15 \%$ gradient Stain-Free gel (BioRad), and proteins in each lane were detected using the ChemiDoc Imaging system (BioRad). Using Image Lab (Bio-Rad) software, densitometry against the BenchMark protein standard (Thermo Fisher Scientific) allowed protein concentrations to be determined. Samples were then diluted to $0.4 \mu \mathrm{g} / \mu \mathrm{L}$ using $1 \times$ LDS buffer.

Then, $10 \mu \mathrm{g}$ of protein from each sample ( 4 biological replicates) was simultaneously reduced and alkylated with $50 \mathrm{mM}$ TCEP and $50 \mathrm{mM}$ chloroacetamide, respectively, for $5 \mathrm{~min}$ at $95^{\circ} \mathrm{C}$. Proteins were then digested in-solution with $500 \mathrm{ng}$ trypsin (Promega) and incubated overnight at $37^{\circ} \mathrm{C}$. Deoxycholate (DOC) was removed by phase transfer using an equal volume of ethyl acetate and acidified to $0.5 \%$ trifluoroacetic acid. The samples were then centrifuged at $14,000 \times g$ for $5 \mathrm{~min}$, and the denser aqueous phase was collected and desalted using SDB-RPS StageTips [60]. The eluted peptides were evaporated to near dryness by vacuum centrifugation and suspended in $\sim 10 \mu \mathrm{L}$ of $0.1 \% \mathrm{FA} / 2 \%$ ACN for proteomic analysis.

\subsection{Mass Spectrometry Analysis and Protein Identification}

The peptides $(4 \mu \mathrm{L})$ were analysed by nanoliquid chromatography-tandem mass spectrometry on a Dionex Ultimate 3000 UPLC coupled to an Orbitrap Fusion Tribrid mass spectrometer (Thermo Fisher Scientific). Peptides were first loaded onto a trap column (Acclaim C18 PepMap nano Trap $\times 2 \mathrm{~cm}, 100 \mu \mathrm{m}$ I.D, $5 \mu \mathrm{m}$ particle size and

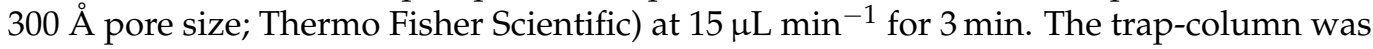
then switched in line with the analytical column (Acclaim RSLC C18 PepMap Acclaim RSLC nanocolumn $75 \mu \mathrm{m} \times 50 \mathrm{~cm}$, PepMap100 C18, $3 \mu \mathrm{m}$ particle size, $100 \AA$ pore size;

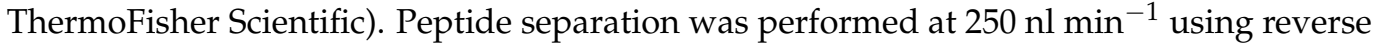
phase chromatography (Buffer A (0.1\% FA, 2\% ACN) and Buffer B (0.1\% FA, 80\% ACN). The non-linear gradient conditions for Buffer B were as follows: $2.5-7.5 \%$ over $1 \mathrm{~min}$, 7.5-37.5\% over $90 \mathrm{~min}, 37.5-42.5 \%$ over $3 \mathrm{~min}, 42.5-99 \%$ over $5 \mathrm{~min}, 99 \%$ hold $6 \mathrm{~min}$, $99-2.5 \%$ over $1 \mathrm{~min}$, and $2.5 \%$ hold $17 \mathrm{~min}$. Data were collected in positive mode using data-dependent acquisition. MS scan properties were as follows: scan range $(m / z) 375-1575$, Orbitrap resolution 120,000, AGC target 1E6, maximum injection time $54 \mathrm{~ms}$, and dynamic exclusion $15 \mathrm{~s}$. MS/MS scan properties were as follows: HCD activation, isolation window of $1.8(\mathrm{~m} / \mathrm{z})$, collision energy 32\%, Orbitrap resolution 30,000, AGC target 2E5, maximum injection time $54 \mathrm{~ms}$.

Raw files were analysed using the MaxQuant platform [61] version 1.5.5.1, searching against a concatenated database consisting of predicted P. sordellii ATCC 9714 coding sequences from the available genome sequence (Genbank accession numbers LN679998, LN679999, and LN680000). Contaminant proteins from the media (yeast proteins (UniProt Proteome ID UP000002311) and casein subtypes (UniprotKB P02666, P02668, P02662 and P02663)) and products encoded by the Group II Intron or pRPF185 vector (ErmB (UniprotKB P20173) and $\beta$-glucuronidase (UniprotKB P05804)) were also identified but removed from further comparative analysis. Spectra were searched with the following criteria: specific digestion mode; maximum 2 missed cleavages; fixed modification of carbamidomethylcysteine; variable modifications of methionine oxidation; and N-terminal acetylation. Labelfree quantification (LFQ), and match between run options were enabled, and false discovery rates of $1 \%$ for proteins and peptides were applied, with 2 minimum peptides required for identification. The raw data from this analysis are provided in Supplementary Data set 1. 


\subsection{Label-Free Quantitative Analysis of Culture Supernatant Proteins}

Analysis of LFQ data was performed using Perseus version 1.5.6.0 [62]. Identified proteins were removed from the dataset if they were not detected in at least 3 out of 4 replicates from at least one strain. The LFQ values were normalised using a $\log _{2}$ transformation. Non-valid values (below the limit of detection) were inputted through random selection of values within \pm 0.2 standard deviations from the mean of the Gaussian distribution of the data set for their respective biological replicate, having first being shifted 1.9 standard deviations to the left. Statistical analysis of LFQ values for two strains for a particular protein was performed using a 2-tailed student's t-test. For screening purposes, the statistical significance cut-off was considered a permutation-based false discovery ratio of 0.1 using 250 randomisations, while implementing an artificial within group's variance of 0.1.

Supplementary Materials: The following are available online at https:/ /www.mdpi.com/article/ 10.3390 /toxins14020124/s1, Figure S1: Confirmation of the insertional inactivation of tcsE of P. sordellii ATCC9714. Confirmation of independent tcsE mutants of P. sordellii ATCC9714 were carried out using Southern hybridization with PstI digested genomic DNA. The blots were hybridized with DIG-labelled DNA probes specific for (a) tcsE, (b) ermB, carried within the group II intron, and (c) catP, carried on the TargeTron vector backbone. V: HindIII digested re-targeted pDLL46 vector; M: DIG-labelled $\lambda$-HindIII molecular size markers (labelled in kb); WT: wild-type isolate. The TargeTron insertion site is present within a $3912 \mathrm{bp}$ fragment on the WT genome producing an $\sim 5712$ bp fragment in correct mutants., Figure S2: A TcdB ELISA that specifically measures TcsL in culture supernatant. Mid-log HIS broth cultures of an isogenic panel of $P$. sordellii strains were diluted to an $\mathrm{OD}_{600}$ of 0.3 before a $1 / 100$ dilution into TY broth and incubated at $37^{\circ} \mathrm{C}$ in an anaerobic environment for $22 \mathrm{~h}$. The culture supernatants were collected and assayed using a TcdB-specific ELISA detection kit (tgcBiomics). Included in the analysis were the wild-type isolate ATCC 9714 (WT), an insertional inactivation mutant of the tcsL gene (tcsLTT) and a pCS1-1 (the plasmid which carried $t c s L$ )-free version of ATCC 9714 (pCS1-1-) obtained as part of a previous study [55,58]. Shown are the absorbance values $(450 \mathrm{~nm}-620 \mathrm{~nm})$ that correlate with TcdB levels, as per the manufacturer's protocol. Absorbance values for decreasing concentrations of purified TcdB (tgcBiomics) are included, along with the average values for 3 biological replicates of $P$. sordellii supernatant. Error bars represent SEM. Figure S3: TcsL toxin levels of supernatants from isogenic strains harvested at $10 \mathrm{~h}$. At $\mathrm{T}=10 \mathrm{~h}$ culture supernatants were collected and assayed using a TcdB-specific ELISA detection kit (tgcBiomics). The concentrations of TcsL detected relative to a TcdB standard protein curve are shown, having been standardised to the total protein concentration in the supernatant, as determined by BCA assays. $n \geq 2$, error bars indicate SEM. Figure S4: Vero cell cytotoxicity assay. Serial doubling dilutions of $P$. sordellii culture supernatants were produced in MEM alpha medium supplemented with $1 \%$ HI FCS and used in cytotoxicity assays. Changes in Vero cell morphology were then scored by microscopy after $24 \mathrm{~h}$. The endpoint was taken as the last dilution at which CPE was observed. The toxin titer represents the reciprocal of the endpoint dilution. WT, wild-type ATCC 9714; tcsE1, tcsE mutant strain DLL5036; tcsE1(V) is DLL5240, the tcsE mutant strain carrying the vector control, tcsE1(tcsE+) is DLL5159, the complemented tcsE mutant. $\mathrm{n}=1$. Table S1: Bacterial isolates and plasmids used in this study. Table S2: Oligonucleotide primers used in PCR and Supplementary File S1: Mass spectrometry data set used for Table 1 and Figure 5.

Author Contributions: Conceptualization, C.J.V., M.A., B.D. and D.L.; methodology, C.J.V., J.W., R.A.M., B.D., M.A. and D.L.; validation, R.A.M.; formal analysis, C.J.V. and R.A.M.; investigation, C.J.V. and A.H.; resources, R.A.M., B.D. and D.L.; writing—original draft preparation, C.J.V., M.A. and A.H.; writing—review and editing, J.W., R.A.M., B.D. and D.L.; visualization, C.J.V., M.A. and A.H.; supervision, B.D. and D.L.; project administration, D.L.; funding acquisition, R.A.M., B.D. and D.L. All authors have read and agreed to the published version of the manuscript.

Funding: D.L. was supported by Future Fellowship FT120100779 (Australian Research Council). This work was also supported by Institut Pasteur (Paris, France). C.J.V. was supported through an Australian Government Research Training Program Scholarship.

Institutional Review Board Statement: Not applicable.

Informed Consent Statement: Not applicable. 


\section{Data Availability Statement: Not applicable.}

Acknowledgments: We thank Julie Singleton for constructing the P. sordellii tcsE mutant. We thank Lucy Li for constructing the tcsE complementation vector and complemented strain.

Conflicts of Interest: The authors declare no conflict of interest.

\section{References}

1. Desvaux, M.; Hébraud, M.; Talon, R.; Henderson, I.R. Secretion and subcellular localizations of bacterial proteins: A semantic awareness issue. Trends Microbiol. 2009, 17, 139-145. [CrossRef]

2. Green, E.R.; Mecsas, J. Bacterial Secretion Systems: An Overview. Microbiol. Spectr. 2016, 4, 1. [CrossRef]

3. Abby, S.S.; Cury, J.; Guglielmini, J.; Néron, B.; Touchon, M.; Rocha, E.P.C. Identification of protein secretion systems in bacterial genomes. Sci. Rep. 2016, 6, 23080. [CrossRef]

4. Natale, P.; Brüser, T.; Driessen, A.J. Sec- and Tat-mediated protein secretion across the bacterial cytoplasmic membrane-Distinct translocases and mechanisms. Biochim. Biophys. Acta (BBA) Biomembr. 2008, 1778, 1735-1756. [CrossRef] [PubMed]

5. Popoff, M.R.; Bouvet, P. Clostridial toxins. Futur. Microbiol. 2009, 4, 1021-1064. [CrossRef]

6. Perelle, S.; Gibert, M.; Bourlioux, P.; Corthier, G.; Popoff, M.R. Production of a complete binary toxin (actin-specific ADPribosyltransferase) by Clostridium difficile CD196. Infect. Immun. 1997, 65, 1402-1407. [CrossRef] [PubMed]

7. Gibert, M.; Jolivet-Renaud, C.; Popoff, M.R. Beta2 toxin, a novel toxin produced by Clostridium perfringens. Gene 1997, 203, 65-73. [CrossRef]

8. Keyburn, A.L.; Boyce, J.D.; Vaz, P.; Bannam, T.L.; Ford, M.E.; Parker, D.; Di Rubbo, A.; Rood, J.I.; Moore, R.J. NetB, a New Toxin That Is Associated with Avian Necrotic Enteritis Caused by Clostridium perfringens. PLoS Pathog. 2008, 4, e26. [CrossRef]

9. Brüggemann, H.; Baumer, S.; Fricke, W.F.; Wiezer, A.; Liesegang, H.; Decker, I.; Herzberg, C.; Martinez-Arias, R.; Merkl, R.; Henne, A.; et al. The genome sequence of Clostridium tetani, the causative agent of tetanus disease. Proc. Natl. Acad. Sci. USA 2003, 100, 1316-1321. [CrossRef] [PubMed]

10. Govind, R.; Dupuy, B. Secretion of Clostridium difficile Toxins A and B Requires the Holin-like Protein TcdE. PLoS Pathog. 2012, 8, e1002727. [CrossRef]

11. Amimoto, K.; Noro, T.; Oishi, E.; Shimizu, M. A novel toxin homologous to large clostridial cytotoxins found in culture supernatant of Clostridium perfringens type C. Microbiology 2007, 153, 1198-1206. [CrossRef]

12. Voneichelstreiber, C.; Boquet, P.; Sauerborn, M.; Thelestam, M. Large clostridial cytotoxin-A family of glycosyltransferases modifying small GTP-binding proteins. Trends Microbiol. 1996, 4, 375-382. [CrossRef]

13. Jank, T.; Aktories, K. Structure and mode of action of clostridial glucosylating toxins: The ABCD model. Trends Microbiol. 2008, 16, 222-229. [CrossRef]

14. Schirmer, J. Large clostridial cytotoxins: Cellular biology of Rho/Ras-glucosylating toxins. Biochim. Biophys. Acta (BBA) Gen. Subj. 2004, 1673, 66-74. [CrossRef] [PubMed]

15. Braun, V.; Hundsberger, T.; Leukel, P.; Sauerborn, M.; von Eichel-Streiber, C. Definition of the single integration site of the pathogenicity locus in Clostridium difficile. Gene 1996, 181, 29-38. [CrossRef]

16. Dupuy, B.; Raffestin, S.; Matamouros, S.; Mani, N.; Popoff, M.R.; Sonenshein, A.L. Regulation of toxin and bacteriocin gene expression in Clostridium by interchangeable RNA polymerase sigma factors. Mol. Microbiol. 2006, 60, 1044-1057. [CrossRef] [PubMed]

17. Mani, N.; Dupuy, B. Regulation of toxin synthesis in Clostridium difficile by an alternative RNA polymerase sigma factor. Proc. Natl. Acad. Sci. USA 2001, 98, 5844-5849. [CrossRef]

18. Matamouros, S.; England, P.; Dupuy, B. Clostridium difficile toxin expression is inhibited by the novel regulator TcdC. Mol. Microbiol. 2007, 64, 1274-1288. [CrossRef]

19. Carter, G.P.; Douce, G.R.; Govind, R.; Howarth, P.M.; Mackin, K.E.; Spencer, J.; Buckley, A.M.; Antunes, A.; Kotsanas, D.; Jenkin, G.A. The anti-sigma factor TcdC modulates hypervirulence in an epidemic BI/NAP1/027 clinical isolate of Clostridium difficile. PLoS Pathog. 2011, 7, e1002317. [CrossRef]

20. Cartman, S.T.; Kelly, M.L.; Heeg, D.; Heap, J.T.; Minton, N.P. Precise Manipulation of the Clostridium difficile Chromosome Reveals a Lack of Association between the tcdC Genotype and Toxin Production. Appl. Environ. Microbiol. 2012, 78, 4683-4690. [CrossRef] [PubMed]

21. Wydau-Dematteis, S.; El Meouche, I.; Courtin, P.; Hamiot, A.; Lai-Kuen, R.; Saubaméa, B.; Fenaille, F.; Butel, M.-J.; Pons, J.-L.; Dupuy, B.; et al. Cwp19 Is a Novel Lytic Transglycosylase Involved in Stationary-Phase Autolysis Resulting in Toxin Release in Clostridium difficile. mBio 2018, 9, e00648-18. [CrossRef] [PubMed]

22. Saadat, A.; Melville, S.B. Holin-Dependent Secretion of the Large Clostridial Toxin TpeL by Clostridium perfringens. J. Bacteriol. 2021, 203, e00580-20. [CrossRef]

23. Wang, I.-N.; Smith, D.L.; Young, R. Holins: The Protein Clocks of Bacteriophage Infections. Annu. Rev. Microbiol. 2000, 54, 799-825. [CrossRef]

24. Saier, M.H.; Reddy, B.L. Holins in Bacteria, Eukaryotes, and Archaea: Multifunctional Xenologues with Potential Biotechnological and Biomedical Applications. J. Bacteriol. 2015, 197, 7-17. [CrossRef] [PubMed] 
25. Mukherjee, K.; Karlsson, S.; Burman, L.G.; Åkerlund, T. Proteins released during high toxin production in Clostridium difficile. Microbiology 2002, 148, 2245-2253. [CrossRef]

26. Sullivan, M.J.; Petty, N.K.; Beatson, S.A. Easyfig: A genome comparison visualizer. Bioinformatics 2011, 27, 1009-1010. [CrossRef]

27. Desvaux, M. Contribution of holins to protein trafficking: Secretion, leakage or lysis? Trends Microbiol. 2012, $20,259-261$. [CrossRef]

28. Wagner, P.L.; Livny, J.; Neely, M.N.; Acheson, D.W.K.; Friedman, D.; Waldor, M.K. Bacteriophage control of Shiga toxin 1 production and release by Escherichia coli. Mol. Microbiol. 2002, 44, 957-970. [CrossRef]

29. Ludwig, A.; Von Rhein, C.; Mischke, A.; Brade, V. Release of latent ClyA cytolysin from Escherichia coli mediated by a bacteriophage-associated putative holin (BlyA) from Borrelia burgdorferi. Int. J. Med. Microbiol. 2008, 298, 473-481. [CrossRef] [PubMed]

30. Hamilton, J.J.; Marlow, V.L.; Owen, R.A.; Costa, M.D.A.A.; Guo, M.; Buchanan, G.; Chandra, G.; Trost, M.; Coulthurst, S.J.; Palmer T.; et al. A holin and an endopeptidase are essential for chitinolytic protein secretion in Serratia marcescens. J. Cell Biol. 2014, 207, 615-626. [CrossRef]

31. Reddy, A.R.S.; Girinathan, B.P.; Zapotocny, R.; Govind, R. Identification and Characterization of Clostridium sordellii Toxin Gene Regulator. J. Bacteriol. 2013, 195, 4246-4254. [CrossRef] [PubMed]

32. Carter, G.; Larcombe, S.; Li, L.; Jayawardena, D.; Awad, M.; Songer, J.G.; Lyras, D. Expression of the large clostridial toxins is controlled by conserved regulatory mechanisms. Int. J. Med. Microbiol. 2014, 304, 1147-1159. [CrossRef]

33. Madeira, F.; Park, Y.M.; Lee, J.; Buso, N.; Gur, T.; Madhusoodanan, N.; Basutkar, P.; Tivey, A.R.N.; Potter, S.C.; Finn, R.D.; et al. The EMBL-EBI search and sequence analysis tools APIs in 2019. Nucleic Acids Res. 2019, 47, W636-W641. [CrossRef]

34. Aunpad, R.; Panbangred, W. Evidence for Two Putative Holin-Like Peptides Encoding Genes of Bacillus pumilus Strain WAPB4. Curr. Microbiol. 2012, 64, 343-348. [CrossRef] [PubMed]

35. Finn, R.D.; Coggill, P.; Eberhardt, R.Y.; Eddy, S.R.; Mistry, J.; Mitchell, A.L.; Potter, S.C.; Punta, M.; Qureshi, M.; Sangrador-Vegas, A.; et al. The Pfam protein families database: Towards a more sustainable future. Nucleic Acids Res. 2016, 44, D279-D285. [CrossRef]

36. Omasits, U.; Ahrens, C.; Müller, S.; Wollscheid, B. Protter: Interactive protein feature visualization and integration with experimental proteomic data. Bioinformatics 2013, 30, 884-886. [CrossRef]

37. Monot, M.; Eckert, C.; Lemire, A.; Hamiot, A.; Dubois, T.; Tessier, C.; Dumoulard, B.; Hamel, B.; Petit, A.; Lalande, V.; et al Clostridium difficile: New Insights into the Evolution of the Pathogenicity Locus. Sci. Rep. 2015, 5, 15023. [CrossRef] [PubMed]

38. Hodak, H.; Galán, J.E. A Salmonella Typhi homologue of bacteriophage muramidases controls typhoid toxin secretion. EMBO Rep. 2012, 14, 95-102. [CrossRef] [PubMed]

39. Govind, R.; Fitzwater, L.; Nichols, R. Observations on the Role of TcdE Isoforms in Clostridium difficile Toxin Secretion. J. Bacteriol. 2015, 197, 2600-2609. [CrossRef] [PubMed]

40. Olling, A.; Seehase, S.; Minton, N.; Tatge, H.; Schröter, S.; Kohlscheen, S.; Pich, A.; Just, I.; Gerhard, R. Release of TcdA and TcdB from Clostridium difficile cdi 630 is not affected by functional inactivation of the tcdE gene. Microb. Pathog. 2011, 52, 92-100. [CrossRef] [PubMed]

41. Voth, D.E.; Ballard, J.D. Clostridium difficile Toxins: Mechanism of Action and Role in Disease. Clin. Microbiol. Rev. 2005, 18, 247-263. [CrossRef] [PubMed]

42. Geiger, T.; Pazos, M.; Lara-Tejero, M.; Vollmer, W.; Galán, J.E. Peptidoglycan editing by a specific ld-transpeptidase controls the muramidase-dependent secretion of typhoid toxin. Nat. Microbiol. 2018, 3, 1243-1254. [CrossRef] [PubMed]

43. Mehner-Breitfeld, D.; Rathmann, C.; Riedel, T.; Just, I.; Gerhard, R.; Overmann, J.; Brüser, T. Evidence for an Adaptation of a Phage-Derived Holin/Endolysin System to Toxin Transport in Clostridioides difficile. Front. Microbiol. 2018, 9, 2446. [CrossRef]

44. Palmer, T.; Finney, A.J.; Saha, C.K.; Atkinson, G.C.; Sargent, F. A holin/peptidoglycan hydrolase-dependent protein secretion system. Mol. Microbiol. 2020, 115, 345-355. [CrossRef]

45. Clark, K.; Karsch-Mizrachi, I.; Lipman, D.J.; Ostell, J.; Sayers, E.W. GenBank. Nucleic Acids Res. 2016, 44, D67-D72. [CrossRef]

46. Riedel, T.; Bunk, B.; Thürmer, A.; Spröer, C.; Brzuszkiewicz, E.; Abt, B.; Gronow, S.; Liesegang, H.; Daniel, R.; Overmann, J. Genome Resequencing of the Virulent and Multidrug-Resistant Reference Strain Clostridium difficile 630. Genome Announc. 2015, 3, e00276-15. [CrossRef]

47. Couchman, E.C.; Browne, H.P.; Dunn, M.; Lawley, T.D.; Songer, J.G.; Hall, V.; Petrovska, L.; Vidor, C.; Awad, M.; Lyras, D.; et al. Clostridium sordellii genome analysis reveals plasmid localized toxin genes encoded within pathogenicity loci. BMC Genom. 2015, 16, 1-13. [CrossRef]

48. Han, X.; Du, X.-D.; Southey, L.; Bulach, D.; Seemann, T.; Yan, X.-X.; Bannam, T.L.; Rood, J.I. Functional Analysis of a Bacitracin Resistance Determinant Located on ICECp1, a Novel Tn916-Like Element from a Conjugative Plasmid in Clostridium perfringens. Antimicrob. Agents Chemother. 2015, 59, 6855-6865. [CrossRef]

49. Skarin, H.; Segerman, B. Plasmidome Interchange between Clostridium botulinum, Clostridium novyi and Clostridium haemolyticum Converts Strains of Independent Lineages into Distinctly Different Pathogens. PLoS ONE 2014, 9, e107777. [CrossRef] [PubMed]

50. Rutherford, K.; Parkhill, J.; Crook, J.; Horsnell, T.; Rice, P.; Rajandream, M.-A.; Barrell, B. Artemis: Sequence visualization and annotation. Bioinformatics 2000, 16, 944-945. [CrossRef]

51. Finn, R.D.; Clements, J.; Arndt, W.; Miller, B.L.; Wheeler, T.J.; Schreiber, F.; Bateman, A.; Eddy, S.R. HMMER web server: 2015 Update. Nucleic Acids Res. 2015, 43, W30-W38. [CrossRef] 
52. Käll, L.; Krogh, A.; Sonnhammer, E. Advantages of Combined Transmembrane Topology and Signal Peptide Prediction-The Phobius Web Server. Nucleic Acids Res. 2007, 35, W429-W432. [CrossRef]

53. Nielsen, H. Predicting secretory proteins with SignalP. In Protein Function Prediction; Kihara, D., Ed.; Humana Press: New York, NY, USA, 2017; pp. 59-73. [CrossRef]

54. McWilliam, H.; Li, W.; Uludag, M.; Squizzato, S.; Park, Y.M.; Buso, N.; Cowley, A.P.; Lopez, R. Analysis Tool Web Services from the EMBL-EBI. Nucleic Acids Res. 2013, 41, W597-W600. [CrossRef] [PubMed]

55. Vidor, C.J.; Watts, T.D.; Adams, V.; Bulach, D.; Couchman, E.; Rood, J.I.; Fairweather, N.F.; Awad, M.; Lyras, D. Clostridium sordellii Pathogenicity Locus Plasmid pCS1-1 Encodes a Novel Clostridial Conjugation Locus. mBio 2018, 9, e01761-17. [CrossRef] [PubMed]

56. Karberg, M.; Guo, H.; Zhong, J.; Coon, R.; Perutka, J.; Lambowitz, A.M. Group II introns as controllable gene targeting vectors for genetic manipulation of bacteria. Nat. Biotechnol. 2001, 19, 1162-1167. [CrossRef]

57. Heap, J.T.; Kuehne, S.A.; Ehsaan, M.; Cartman, S.T.; Cooksley, C.M.; Scott, J.C.; Minton, N.P. The ClosTron: Mutagenesis in Clostridium refined and streamlined. J. Microbiol. Methods 2010, 80, 49-55. [CrossRef] [PubMed]

58. Carter, G.P.; Awad, M.; Hao, Y.; Thelen, T.; Bergin, I.L.; Howarth, P.M.; Seemann, T.; Rood, J.I.; Aronoff, D.M.; Lyras, D. TcsL is an Essential Virulence Factor in Clostridium sordellii ATCC 9714. Infect. Immun. 2011, 79, 1025-1032. [CrossRef]

59. Cheung, J.K.; Wisniewski, J.A.; Adams, V.M.; Quinsey, N.S.; Rood, J.I. Analysis of the virulence-associated RevSR two-component signal transduction system of Clostridium perfringens. Int. J. Med. Microbiol. 2016, 306, 429-442. [CrossRef]

60. Kulak, N.A.; Pichler, G.; Paron, I.; Nagaraj, N.; Mann, M. Minimal, encapsulated proteomic-sample processing applied to copy-number estimation in eukaryotic cells. Nat. Methods 2014, 11, 319-324. [CrossRef] [PubMed]

61. Cox, J.; Mann, M. MaxQuant enables high peptide identification rates, individualized p.p.b.-range mass accuracies and proteomewide protein quantification. Nat. Biotechnol. 2008, 26, 1367-1372. [CrossRef]

62. Tyanova, S.; Temu, T.; Sinitcyn, P.; Carlson, A.; Hein, M.Y.; Geiger, T.; Mann, M.; Cox, J. The Perseus computational platform for comprehensive analysis of (prote)omics data. Nat. Methods 2016, 13, 731-740. [CrossRef] [PubMed] 